SHS Web of Conferences 24, 01017 (2016)

DOI: $10.1051 /$ shsconf/20162401017

(C) Owned by the authors, published by EDP Sciences, 2016

\title{
On protection of employee rights and interests in management of tourist hotel in China
}

\author{
Yun Ren \\ School of Tourism, Hainan University, Haikou, Hainan, China
}

\begin{abstract}
With the rapid development of the tourist hotel, the hotel has many problems in the protection of employee rights and interests. To enhance the importance that hotel managers attach to the protection of employee's rights and interests, and strengthen the hotel employees' consciousness in rights protection, this paper regards the China's tourist hotel employees as research objects, discusses the problems and causes in the process of protecting the tourist hotel employee rights and interests, and proposes solutions with the basic idea of "discovering, analyzing and solving problems".
\end{abstract}

Keywords: China's tourist hotel; protection of employee rights; problems and solutions

\section{PROBLEMS IN THE PROTECTION OF EMPLOYEE RIGHTS AND INTERESTS IN THE MANAGEMENT OF TOURIST HOTEL IN CHINA}

\subsection{Low labor remuneration}

Labor remuneration is obtained by the laborers through their physical or mental labor, reflecting the social value created by the laborers. It includes the monetary wages, physical remuneration and social insurance. In China, the wage is generally low for the tourist hotel employees and even lower for the hotel interns. Compared with increasingly rising commodity price, the wage level is very unfavorable for employees. However, some hotels even view the reduction in employee compensation as an effective way to reduce the enterprise cost. Compared with the in-service employees in urban units, the overall compensation level in the hotel industry is much lower than that of other industries, and the labor remuneration obtained by the employees is relatively low, thus directly causing that the hotel employees quit the job when their hard work fails to obtain due reward, which is also a major impact for the hotel to confront with the "labor shortage".

\subsection{Long working hours}

Article 36 of Labor Law stipulates that, "Our country practices a working hour system wherein laborers should work for no more than eight hours a day and no more than 44 hours a week on the average." However, the ceiling of working hours and the floor of rest time implemented in most tourist hotels are not in line with the relevant provisions of the labor law, and most tourist hotels fail to balance the work and rest demands of employees. In the tourist hotel industry, the workload of employees remains to be heavy, thus they cannot enjoy their rights about the regular rest and holiday. The tourist hotel industry is lack of uniform executive standards. The working hours of most hotel employees are beyond the statutory working hours. And the tourist hotels generally do not provide employees with economic compensation corresponding to the appropriate mandatory standards, and enforce employees to work overtime on the grounds that working overtime in the hotel industry is the work demand, without overtime pay or a small amount of overtime pay. For controlling over working hours and overtime compensation in holidays, the legitimate rights and interests of the tourist hotel employees are seriously infringed.

\subsection{Weak labor safety protection}

In the tourist hotel, a low signing rate of the labor contract is the largest hidden danger for the labor safety of employees. When the rights and interests of employee are infringed, a lot of problems won't be 
solved if there is no formal written labor contract signed between the employees and the hotel. Without the labor contract, it is very unfavorable for employees even by using legal means to safeguard their rights and interests, which is also a key reason of failure in fully guaranteeing the employees' rights and interests.

\subsection{Untimely employee training with bland content}

The vocational training for the hotel employees is not only an obligation of the enterprise, but also the employee's right. Article 3 of Labor Law stipulates that, "The laborers have the right to get training in professional skills." However, in the tourist hotel, some enterprises fail to realize the training programs promised for the employees due to various reasons. After the evaluation and sending offer to a new employee, many enterprises still wait to recruit enough new employees and then carry out centralized training. The employees are not familiar with the hotel facilities and services at work, thus generally resulting in guest dissatisfaction. Some hotels provide training for the employees. However, due to training content, outdated training methods, single form and poor innovation, the employees have insufficient understanding of training and passively accept training so that the effect is not ideal.

\subsection{Complicated complaint procedures}

Tourist hotels basically set up procedures to deal with customer complaints, but few set up special complaint procedures for the employees. When the employee's rights are infringed, the hotel departments will shirk their responsibility to deal with events with equivocal words, leading that the employee's rights and interests fail to obtain sufficient and specific safeguard. In terms of the external complaints, when the employee's rights and interests are infringed and they fail to obtain reasonable disposal in the hotel, the employees can safeguard their rights by using legal weapons such as complaint or petition letter, applying for labor arbitration and instituting legal proceedings or other procedures. However, the employees are generally reluctant to adopt such complicated procedures. In handling various formalities, it will cost a lot of material costs and time costs of the employees. Therefore, the hotel employees will consider to protect their rights by laws only when they suffer from severe infringement and heavy losses.

\section{ANALYSIS OF CAUSES OF PROBLEMS IN PROTECTION OF TOURIST HOTEL EMPLOYEE RIGHTS AND INTERESTS}

(1) Sharp contradiction between supply and demand of labor force from the perspective of economy

From the perspective of economy, the fundamental reason of a series of problems in labor relations of the tourist hotel is determined by sharp contradiction between supply and demand in China's labor market. China's laborers confront with unprecedented employment pressure. On one hand, the supply of the middle and low-level employees in the tourist hotel exceeds demand. It is predicted that, in the next few years, the number of employees in the cities and towns will be still more than 25 million per year. However, the transfer of 200 million of excessive rural labor force is undoubtedly a huge problem to be solved in the labor supply and demand. Under the background of such a labor force, the hotel industry as the tertiary industry absorbs a lot of laborers. The threshold of the tourist hotel industry is relatively low, the work with strong repeatability is simple and easy-to-learn, what's worse, low-education laborers can also engage in the corresponding work in the hotel, and these three factors result in relatively intense competition among the employees and the job seekers in the tourist hotel industry, so the labor relation tends to be strained. On the other hand, the middle and high-level employees, especially senior managers in the tourist hotel industry require to being highly-educated, with strong specialty. Compared with the foreign-funded hotels, Chinese hotels have less proportion in the same educational level and specialty of the middle and high-level managers. The demand of middle and high-level employees of the tourist hotel exceeds supply.

(2) Deficiency in relevant system of protecting the employee rights and interests from the perspective of system

Viewing from summary and analysis of the current employee protection system of the tourist hotel, there are a lot of problems in the hotel employee rights and interests protection system. The deficiency in the system seriously affects the construction of the employee rights and interests protection system of the tourist hotel. These problems can be concluded to three categories. First, the system is too abstract and vague with insufficient concrete, quantifiable and easy-to-operate and test provisions so that the result often causes a chance for subjective intent. Second, the general provision is more complete, but without enough provisions in dealing with special problems. It pays more attention to protect the material interests of the hotel employees, but less attention to protect the spiritual benefits and personality benefits. Third, some provisions are not fulfilled due to limited capacity of the hotel, which actually become mere "paper talk". And many hotels fail to strictly implement the relevant provisions of the Labor Law and the Labor Contract Law. Due to the lack of strict supervision and management mechanism, the hotel even reduces the operating costs through infringing the legitimate rights and interests of employees. Meanwhile, the labor unions and employees' assembly fail to be truly run based on the employee rights and interests. The ability, material 
resources, financial resources and energy of the damaged employees are limited so that the employee rights and interests are not safeguarded timely. As time passes, it reduces major issues to minor ones.

(3) Poor physical strength of employees in safeguarding rights by using legal weapons from the perspective of law

Article 6 of the Regulations of the People's Republic of China on Settlement of Labor Disputes in Enterprises stipulates that, "In case of a labor dispute, the parties should first find solution through negotiations. If the parties are unwilling to go for negotiations or negotiations fail, the case may be referred to the labor dispute mediation committee of the enterprise in which the dispute has occurred; if mediation fails, the case may be referred to the labor dispute arbitration committee for arbitration. The parties may also petition directly to the labor dispute arbitration committee for arbitration. When one of the parties or both parties refuse to accept the arbitration award, he or they may bring a law suit before the people's court. In the course of handling a labor dispute, neither party should take any action that may aggravate the dispute." These provisions provide a way to settle disputes for the laborers. However, only a small part of employees choose to safeguard their rights by the use of legal means when the legitimate rights and interests of the employees are infringed. The main reasons are as follows: First, the employees' power is poor. Compared with the hotel, the employee as an individual belongs to a vulnerable group, whose material costs and time costs are extremely limited; second, the procedures of safeguarding rights by the law are complicated, and the procedures of labor dispute settlement is too complicated with too many links, and the employees are generally lack of the corresponding law knowledge and unfamiliar with the complaint procedures; third, the legal consciousness of the employees is weak, with attitude towards "the less trouble the better". The above three factors make the employees do not tend to safeguard their own legitimate rights and interests by the use of legal weapons.

(4) Unclear understanding of their own rights by the employees from the perspective of individuals

The employees are not clear of their own rights so that the hotel has the chance to infringe the legitimate rights and interests of the employees. First, the employees not completely understand whether the hotel pays social insurance for them, nor the different circumstances of the insurance. Second, they are not clear of the rights under the labor contract signed with the hotel. The lower the hotel star level is, the lower the signing rate of the labor contract is. Third, the compensation standards for working overtime and working in holidays are not clear.

\section{SOLUTIONS TO PROTECTION OF EMPLOYEE RIGHTS AND INTERESTS OF THE TOURIST HOTEL}

\subsection{Government's point of view}

1. To improve the relevant laws and regulations, and detail the rules of protecting the hotel employee's rights and interests

The basic laws are improved. The Labor Law of the People's Republic of China and Labor Contract Law are authoritative laws to protect the legitimate rights and interests of the laborers, but some provisions are too vague. With continuous development of the socialist market economy, the relevant laws and regulations should be also constantly adjusted and improved. The provisions with too much principle and poor operability should be enriched, and the existing labor dispute mediation system, arbitration system and litigation system should be improved, and the rules of protecting the hotel employee's rights and interests should be detailed, which are the most basic measures to strengthen the protection of employee's rights and interests.

2. Strengthen law enforcement efforts and improve the supervision mechanism

As the most powerful backing of the people, the government should safeguard the hotel employee rights and interests well. The Labor Law of the People's Republic of China and the relevant laws and regulations make a corresponding provision to protect the legitimate rights and interests of laborers, including the tourist hotel employees. The government and safety supervision departments at all levels should strengthen the implementation of supervision and inspection of the safety production laws for the hotels, so as to ensure the health and safety of employees, and really achieve the function of government supervision. The labor supervision department should be responsible for the labor contracts and collective contracts. The government should regularly publish the hotel labor contracts, payroll and other situations to the public, and realize real transparency. Therefore, to strengthen law enforcement efforts and improve the supervision mechanism is imperative to protect the legitimate rights and interests of the employees.

3. Strengthen the efforts of popularizing laws and enhance the employee's consciousness of rights safeguarding

The governmental propaganda department should regularly teach the labor law, trade union law and other laws and regulations for the hotels and employees, and strengthen publicity by the use of news media, so everyone knows the guarantee of employee rights and interests and considers that it is deserved to strive for own legitimate rights and interests. On the other hand, appropriate media exposure can also be adopted to cause widespread concern in all walks of life, for example, reporting the illegal events of some hotels. 


\section{SHS Web of Conferences}

Thus, strengthening the efforts of popularizing laws and enhancing employee's consciousness of rights safeguarding is extremely urgent.

\subsection{Enterprise's point of view}

\subsubsection{Update the management philosophy}

With the innovation of the modern management concept, the people-oriented management philosophy is raised once again, and the dominant position of the employees is confirmed. The tourist hotel industry should timely update the operation philosophy and implement the concepts such as "employee first, customer second", "without satisfied employees, no satisfied customers" and others, attach great importance to protect the rights and interests of the hotel employees, safeguard the legitimate rights and interests of the employees, establish and improve the hotel talent transport network, balance the work and rest demand of employees, improve the salary management system and a series of employment systems, and also refer to the advanced foreign management philosophy to promote good and healthful development of the hotel industry.

\subsubsection{Improve the management system}

As the hotel managers, they must follow the following principles in the protecting employee's rights and interests: The first is the legal principle. The managers should be familiar with the relevant labor laws, regulations and the rules and regulations of the hotel, and hire employees, promote employees, dismiss employees in accordance with the laws and regulations, and legal procedures. The second is the moral principle. First of all, the hotel managers should place the protection of employee's rights and interests and the provision of quality services in an equal important position; second, the employee's rights and interests are protected by the moral standards so that the employee management of hotel is more humane and reasonable. Therefore, the tourist hotel should only constantly innovate the management system, view the employees as the foundation, implement humane management from the perspective of employees and adequately protect the employees' rights and interests, so as to improve the service quality of the hotel, promote the economic benefit, enhance the overall competitiveness and achieve the stable and healthy development of hotel management and the team construction of hotel employees.

\subsubsection{Implement management rules}

The tourist hotel shall also have a set of practical, quantitative and strict operating procedures after developing the corresponding rules, so as to provide the employees with a smooth reporting channel. The hotels are also obliged to increase the efforts to publicize the Labor Contract Law, popularize laws and actively adjust and flexibly develop the employment system of the hotel, and effectively protect the legitimate rights and interests of the employees. The work quality of the employees is closely related to the degree of protecting their rights and interests. The hotels implement people-oriented management philosophy and management rules, improve lifelong employability of the employees, and establish new labor relations, which contribute to achieving optimal preparation of the means of production and motivate enthusiasm.

\subsection{Personal point of view}

\subsubsection{Enhance legal accomplishment and strengthen consciousness of rights safeguarding}

In addition to participating in the activities involved in popularizing laws and receiving the corresponding law knowledge, the hotel employees should also consciously actively understand the labor law and other laws and regulations closely related to themselves before job hunting and during work in the hotel, so as to enhance legal accomplishment and strengthen the consciousness of rights safeguarding.

\subsubsection{Be familiar with skills and methods of protecting rights of the hotel employees}

The first method is consultation. When the legal rights and interests of the employees are infringed, there is a first need to consult with the enterprise in an amicable way. The second method is complaint. If the negotiation fails, and the rights and interests of the employees are seriously infringed, the employees can give priority to make a complaint to the local labor security department or local government, so as to correct the violations of the enterprise through the administrative supervision by the administrative organs, and achieve the goal of safeguarding the rights and interests of the employees. This method of safeguarding rights has a relatively high efficiency, but with low costs. The third method is petition letter. If the rights and interests of the employees is infringed and, there are a large number of employees, the representatives can be appointed to the government complaint department to reflect problems, and the government generally attaches importance to them, and the rights and interests can be timely protected. If there are a small number of employees, it is better to directly make complaints to the labor department, generally with a higher efficiency. The fourth method is labor arbitration. If the problems are not resolved by the above methods, the rights and interests of the employees can only be protected by the labor arbitration. The fifth is litigation. If the arbitration result of the labor arbitration institution is unfair, it can be sued to the people's court according to law. The sixth is arbitration award and written judgment applied for enforcement with legal efficiency. The employees should not use illegal means to protect rights, or otherwise events will get worse. 
In short, the protection of rights and interests of the tourist hotel employees should be upgraded to a strategic height in the government and enterprise management, so as to achieve the benign development of the hotel. Rather than blind pursuit of low costs, the harmonious labor relation is the basis of a tourist hotel's competitiveness. In the society of knowledge economy, the hotel industry will not only confront with the problems of how to grasp the market and how to improve the hardware level, but more importantly, make full use of the enterprise resources to truly achieve the "people first" and "employee first". The competition in the hotel industry boils down to the talent competition. Hotels should put the rights and interests protection of the employees in a strategic height of the government and hotel management, and constantly convert the labor employees into human resources. This is a golden key to success for the tourist hotel, thus the tree of the enterprise will be evergreen.

\section{REFERENCES}

[1] Xie Yan. 2009. On employee protection in the touris hotel. Enterprise Technology and Development. (2): 41-42.
[2] Wang Xiaolu. 2007. Research on human resource management of tourist hotel based on the new Labor Contract Law. 26.

[3] Zhuang Yuan. 2009. Research on Labor Relationship of Tourist Hotel Based on Labor Contract Law. Tourism Management Department of China Ocean University. pp.19-21.

[4] Liu Qiming. 2005. Construction of employee rights and interests protection system and harmonious private enterprise. Journal of Hubei Administration Institute, (6): 38-39.

[5] Lin Hua. 1996. Increase efforts to standardize labor relations--implement Labor Law by the tourist hotel. China Labor Movement, (3): 38-39.

[6] Gu Huimin. 2000. Research on current situation and countermeasures of human resource management of hotel with foreign management in Chinese Mainland. Tourism Tribune, (5): 68-73.

[7] Song Zibin \& Chen Zhaoyang. 2006. Empirical research on job satisfaction of undergraduate interns with the tourism major and job hunting intention in the tourism industry. pp.106-107.

[8] Solon. 2002. The Art of Employing. China Textile Press.

[9] Song Haiying. 2010. Protection of employee rights and interests to allow enterprises to go further. Journal of Glory, (13): 5-13.

[10] Zhang Xiaotong. 2003. Employee Relation Management. Peking University Press, 9.

[11] Wu Xiaoping. 2004. How to Enhance Employee Satisfaction and Professional Dedication. Peking University Press, 4. 